Article

\title{
Visual Exposure of Rock Outcrops in the Context of a Forest Disease Outbreak Simulation Based on a Canopy Height Model and Spectral Information Acquired by an Unmanned Aerial Vehicle
}

\author{
Marie Balková ${ }^{1, *(1)}$, Aleš Bajer ${ }^{1}$, Zdeněk Patočka $^{2}\left(\mathbb{D}\right.$ and Tomáš Mikita ${ }^{2}$ (I) \\ 1 Department of Geology and Pedology, Faculty of Forestry and Wood Technology, Mendel University in Brno, \\ 61300 Brno, Czech Republic; ales.bajer@mendelu.cz \\ 2 Department of Forest Management and Applied Geoinformatics, Faculty of Forestry and Wood Technology, \\ Mendel University in Brno, 61300 Brno, Czech Republic; zdenek.patocka@mendelu.cz (Z.P.); \\ tomas.mikita@mendelu.cz (T.M.) \\ * Correspondence: marie.balkova@mendelu.cz; Tel.: +420-545-134-040
}

Received: 6 April 2020; Accepted: 4 May 2020; Published: 15 May 2020

\begin{abstract}
This research was focused on the study of visual exposure evolution in the locality of the Drátenická skála nature monument (in the Czech Republic) and the surrounding forest complex in terms of history and through modelling for further possible stand development. The local forests underwent conversion from a natural fir-beech composition to an intensive spruce monoculture with few insect pests or windbreak events to an actual bark beetle infestation. Historic maps, landscape paintings, photographs, and orthophotos served as the basic materials for the illustration of the past situation. Further development was modelled using canopy height models and spectral properties captured by unmanned aerial vehicles (UAVs). As an example, the possible situation of total mortality among coniferous spruce trees after a bark beetle outbreak was modelled. Other options and a practical use of such preprocessed data are, for example, a model for opening and transforming the stands around the rock as one of the ongoing outcrop management trends in the protected landscape area (PLA) of Žd'árské vrchy.
\end{abstract}

Keywords: canopy; image classification; orthophoto; historical maps; UAV; NDVI; digital terrain model; digital surface model

\section{Introduction}

The authors would like to dedicate this article to the memory of Associate Professor Jan Lacina, who passed away on 21 March 2020. He was a Czech forester with the soul of poet and was a geobioecologist; lover of nature, birds, and landscape painting; and a tireless advocate of forest science. Many thanks to him for providing the inspiration for this article and helping with the search for paintings by artists from Žd'árské vrchy-a landscape he liked a lot.

Visual exposure is a habitat characteristic that might not seem important at first. However, vegetation cover in localities with protruding rock outcrops could be the key factor in the life conditions for animal and plant species that occur specifically in this environment. This study targeted the protection of rock outcrops, which are considered to be specific microecosystems and are biodiversity hotspots facing the threats and impacts of ongoing climate change [1,2]. They are refuges for flora and fauna from the surrounding adversely human-affected landscape and have unique characteristics for life [3]. These areas remove unfavourable edaphic, nutrient, temperature, and other climatic conditions, 
and along with providing topographic heterogeneity, they also serve as suitable habitats for endemic species that require a specific environment [4].

\subsection{Aim of the Study}

In this study, we primarily aimed to describe the vegetation development around Drátenická skála, as it is one of the most attractive localities that has been influenced by humans or by natural processes in the past. We also investigated its possible future state, which could be decisive for the suitability for many organisms. Using geographical information systems (GIS) analyses, we modelled the possible visual exposure of the stands after a controlled intervention or a natural outbreak [5] and compared the situation over the last centuries through the use of:

- landscape painting and historical maps,

- historical and current photographs and orthophoto, and

- unmanned aerial vehicle (UAV) remote-sensing data and digital terrain and surface models.

\subsection{Landscape Painting}

Painting is the oldest method of depicting reality. It began in prehistory, when our ancestors painted on cave walls and other artefacts. The ochre lines on the stone from the Blombos Cave (South Africa) are probably the oldest known human drawing. They have been dated to Middle Stone Age and determined to be 73,000 years old [6]. Other thousand-year-old paintings of animals on cave walls are known from France, Germany, and Spain [7]. We can speculate about their purpose, but there are several explanations. They could have served as messages about the presence of the depicted animals as the main source of a meal [8], as the oldest schemes or maps, or even for ritualistic purposes [9]. In connection to the evolution of the human brain, these drawings could also have been a form of personal expression. Over time, painting became a form of art with many directions and styles. Landscape painting seems to be a unique style that developed in the 17th century in the Netherlands and reached its prime during the 19th and 20th centuries. This then led to the development of several artistic styles, such as romanticism, realism, modernism, and impressionism, which were used by painters such as Jacob Ruisdael, El Greco, Carlos de Haes, Frederic Edwin Church, Pablo Picasso, Paul Cézane, Claude Monet, and Vincent van Gogh. In Czech lands, the history of landscape painting began roughly in the 19th century, as our artists were influenced by French Barbizon and other European schools. The most significant Czech landscape painters included Maxmilián Haushofer, Antonín Mánes, Julius Mařák, Otakar Nejedlý, František Kaván, Antonín Slavičck, Oldřich Blažíček, and Josef Jambor [10].

\subsection{Remote Sensing}

The phenomena of modelling the Earth's terrain shapes began with the development of geographical information systems (GIS) and remote sensing (RS). One of these terrain-modelling technologies is light detection and ranging (LiDAR), which is built on the principle of a laser beam reflection from the Earth's surface. Laser scanners are active systems that emit light pulses and record their energy. These readings are carried out by a specially constructed airplane. Other components of this system are the length measurement unit, the control and recording unit, the IMU (inertial measurement unit)/global navigation satellite systems (GNSS) unit, and the imaging unit [11]. By calculating the measured values of the distance and time between the emission and reception of the laser beam and determining the reflection place, the $\mathrm{X}, \mathrm{Y}$, and $\mathrm{Z}$ coordinates of the points are exactly determined, and a point cloud is generated. Using several interpolating methods, the models of surface and terrain can be calculated [12]. Currently, in the Czech Republic, we are able to work with the first-generation digital surface model (DSM 1G), which has an accuracy of $0.7 \mathrm{~m}$ for vegetation and $0.4 \mathrm{~m}$ for buildings [13,14], and the fifth-generation digital terrain model (DTM 5G), which has an accuracy of approximately $0.18 \mathrm{~m}$ in open terrain and $0.3 \mathrm{~m}$ in terrain covered by vegetation $[13,15]$. 
Currently, there is a growing interest in the use of unmanned aerial systems and the structure-from-motion (SfM) algorithm in forestry. This technology has been most studied for use in forest inventories [16]. Typically, the created canopy height models and spectral information are used to estimate forest variables [17]. A further application field is the monitoring and assessment of forest health conditions. For this purpose, a combination of 3D models with 2D spectral properties are often used and obtained using multispectral sensors and are also used in the previous cases $[18,19]$. Complex studies dealing with the UAV-based estimation of forest variables such as the dominant height, Lorey's mean height, stem density, basal area, and timber volume have yielded the work of Puliti et al. [20] and Tuominen et al. [21]. In temperate forests, Mikita et al. [22] determined the biophysical forest parameters using a combination of UAV and close-range photogrammetry. Methods for UAV-based forest inventory can be divided into area-based approaches (ABA) [23] and individual tree crown (ITC) approaches [24]. ITC enables the detection of trees with an accuracy of $25 \%$ to $90 \%[25,26]$, to classify them by tree species with an accuracy of up to $95 \%$ [27] and to measure tree heights with an RMSE ranging from 0.5-2.84 $\mathrm{m}[25,28]$.

Currently, the role of remote sensing in forestry is growing, especially for the purpose of assessing the forest health status. Remote sensing enables the rapid and objective evaluation of a wide area of forests. Using multi- or hyperspectral sensors, it is possible to determine the content of chlorophyll, water, and leaf pigments [29]. The acquisition of discrete spectral data using UAVs is possible, because many lightweight sensors have been developed in recent years. However, compared to RGB cameras, multispectral cameras are characterised by lower resolutions [16]. Unlike agriculture, where spectral information is already routinely used, there are only a few studies in forestry dealing with the use of spectral data acquired by UAVs. Näsi et al. [30] used a combination of the ITC approach and hyperspectral data as a cost-effective alternative to field-based monitoring of bark beetle infestation. According to Minařík and Langhammer [31], the red edge and NIR part of the electromagnetic spectrum are the most useful for stress monitoring. The normalized difference vegetation index, especially in time series and in conjunction with the random forest classifier, may be one of the best predictors for mapping physiological stress [32]. The main reason for using UAVs is above all the high flexibility, which is especially advantageous today, when forests are changing rapidly due to climate change and related diseases. The minor reason for creating the UAV/SfM-based canopy height model was the high point density compared to the general LiDAR product, DTM 5G. It should be noted that the minimum LiDAR point density required for the creation of canopy height models is approximately 5 pts per square metre, and the average density of available LiDAR data for this locality is 1 point per 10 square metres [33].

In regard to specific rock outcrop research, there are many studies aimed at rock outcrop modelling using different remote sensing technologies or terrestrial laser scanning; in some cases, the studies are also connected with structural geological surveys [34-38]. With increasing technologies, outcrop modelling is not limited only to the Earth but is also performed within the solid-state planets or moons of the solar system [39]. We can also mention the previous research of the authors' team, which compared different 3D models of boulders [40]. In the locality of Žd'árské vrchy, few studies dealing with outcrop management have been performed; one of the few from recent years was a study of Malinská skála and identification of its outcrops [5].

\section{Materials and Methods}

\subsection{Protected Landscape Area Žd'árské vrchy}

The highland of Žd'árské vrchy is situated in the Central Czech Republic, Vysočina and Pardubice regions (Figure 1) on the "roof of Europe", where the main divide of the European Elbe-Danube rivers runs through. The area is well-known for its specific landscape characteristics, which comprise typical geomorphological forms, rock formations, deep forests, scattered vegetation, stone pastures, flowery meadows, river systems, and preserved natural habitats completed by elements of folk architecture and harmonious coexistence of humans. All these phenomena were and are endangered by human 
expansion and misuse of the entrusted nature wealth, which started with Middle Ages colonisation-the first written indication of a settlement is from 1420 [41,42]. The protected landscape area (PLA) was proclaimed in 1970 by an announcement of the Ministry of Culture of the Czechoslovak Socialistic Republic and covers over 70,000 ha [43]. The subject of protection was defined by this announcement, which says [44]: "The mission of the locality is the protection of the local landscape, its looks and typical features to create a harmonious environment. Within these typical landscape features, the specific surface formations include the watercourses and water areas, design and use of forest and agricultural land funds, vegetation cover and wildlife, housing estate structure, urban composition of housing estate, local folk architecture and considerable or dominant forms of production." The following purposes are considered to be the most important and seem to be the most related to our topic: preservation and manging the natural forest ecosystems, increasing the ecological stability, and conserving typical abiotic natural features and landscape characteristics.

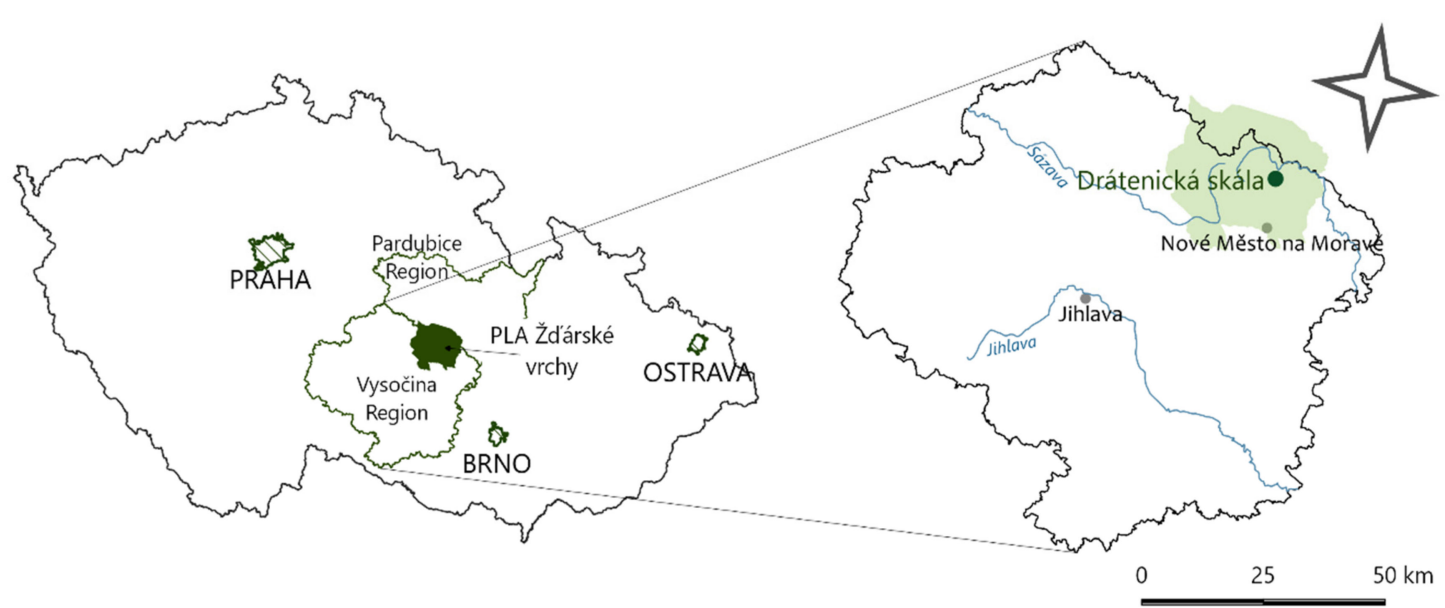

Figure 1. Localisation of Drátenická skála within the Czech Republic.

\subsubsection{Geology and Geomorphology}

The PLA consists of several geological units of the Czech Massif formed during the Varisk folding in the Palaeozoic (Devonian and Carboniferous). In the Central and Northwestern parts, we can find the largest one, Svratka Crystalinicum, with migmatites, double-daize orthogneisses, and mica schists. The most significant features are outcrops of coarse grain augen orthogneisses with amphibolites and scarns. Minor features were formed in Strazec Mouldanubicum with paragneisses, amphibolites, crystalline limestone, and serpentinites, and then, Polička Crystalinicum with gneisses, Iron Mountains pluton with granites and porphyries, Hlinsko zone with phyllites, Ransko massif with eruptive rocks and iron ores, and finally, the area of the Czech Cretaceous Formation with lime sandstones, claystones, and marlites. During the next geological period-the Pleistocene-the outcrops were influenced by cryogenic weathering, creating karstic and stone sediments and fallow fields. Alluvial river terraces and moors were formed during the Holocene [45-47].

The local landscape is well-known for its characteristic large ridges and widespread river valleys between them. This macro-relief has cryogenic microstructures, e.g., rock outcrops, tors, and frost cliffs surrounded by fallow fields and cryoplanation terraces. All these geomorphological phenomena are a significant part of the local geoheritage based on the nature of geodiversity. The importance of geoheritage has been rising recently as we have increasingly aware of the need for geosite (or geomorphosite) protection [48,49].

\subsubsection{Flora and Fauna}

The area was covered by dense primeval forest until medieval colonisation in the 13th century. Fragments of that natural forest have been preserved until the present day and are usually located 
around ridges with outcrops; all of them are the objects of conservation [42]. Several botanical surveys have been carried out, and they mention, for example, the following significant botanical species from many plant communities (e.g., [50]). The typical vegetation compositions of these stands are acidophilic spruce beechwoods (Luzulo-Fagion), with beech (Fagus sylvatica L.), spruce (Picea abies (L.) H. Karst), and fir (Abies alba Mill.) as the dominant wood species [51]. In some places, residual moors and waterline spruce woods are extant with other tree species-pines (Pinus sylvestris L. and P. rotundata L.). Representatives of other less dispersed stands and communities are preserved in several protected landscape sites, as is the herbal cover of rare plant species (Leucojum vernum L., Aconitum variegatum L., Vaccinium uliginosum L., Oxycoccus palustris Pers., Eryophorum vaginatum L., and Sphagnum sp.). The majority of these species were replaced by Norway spruce production forest. Additionally, on nonforest protected sites, such as standing and running water ecosystems, reeds, moor meadows, or heaths [34], it is possible to view a wide range of rare vascular plant species, e.g., Caricion sp., Carex sp., Sphagnum sp., Trichoporum alpinum L., Drosera rotundifolia L., Dactylorhiza majalis (Rchb.) P. F. Hunt et Summerh., and Nymphaea candida J. Presl [43].

In this locality, montane and submontane wildlife species are preserved in high numbers, specifically in the fragments of beech stands, wet moors and heath meadows, bank stands, or wetlands. There are 160 species of birds: white stork (Ciconia ciconia L.), Eurasian sparrowhawk (Accipiter nisus L.), northern goshawk (Accipiter gentilis L.), and Eurasian eagle owl (Bubo bubo L.) and 53 species of mammals: western barbastelle (Barbastella barbastellus Schr.), lesser horseshoe bat (Rhinolophus hipposideros Bech.), Eurasian otter (Lutra lutra L.), and European badger (Meles meles L.). In addition, common game species occur, and the natural population of red deer (Cervus elaphus L.) in game-keeping area Žd'árské vrchy seems to be most significant. Roe deer (Capreolus capreolus L.), wild boar (Sus scrofa L.), or fox (Vulpes vulpes L.) are commonly observed. Additionally, reptiles: the viviparous lizard (Zootoca vivipara Lich.) and European viper (Vipera berus L.); amphibians: alpine newt (Ichthyosaura alpestris Laur.) and common frog (Rana temporaria L.); and hundreds of species of invertebrates: European crayfish (Astacus astacus L.), common ringlet (Coenonympha tulila Müll.), cranberry blue (Agriades optilete Knoch), and Formica sp. are important parts of the local ecosystems [42]. Additionally, gastropods and spiders are represented by a high number of species $[52,53]$

\subsubsection{Drátenická Skála}

Drátenická skála nature monument is situated in the Blatiny cadastral area, which has an altitude of $776 \mathrm{~m}$ and is the highest outcrop peak in the area. The rock belongs to Svratka Crystalinicum double-daize migmatites and orthogneisses. This 200-m rock ridge is considered to be a relict frost cliff with a few isolated tors. The main rock block consists of several tors (towers) with passes between them (Figure 2). Sokolí věž is the highest (35 m), and the others include Orlí věž, Otoman, Zbojnická věž, and Indiánská věž. Krakonošova zahrádka is a ravine with rocks bedded alongside the foliation layers. Around the blocks, fallow rock fields and boulder streams spread. Additionally, many microrelief features can be found, such as abri, rock tunnels, rock windows, or honeycombs. Furthermore, some geological processes can be observed, such as well-developed joint systems, cryogenic weathering, and rock collapse. The locality is also strongly influenced by humans because of intensive rock climbing and visits by thousands of tourists during the year $[54,55]$. 


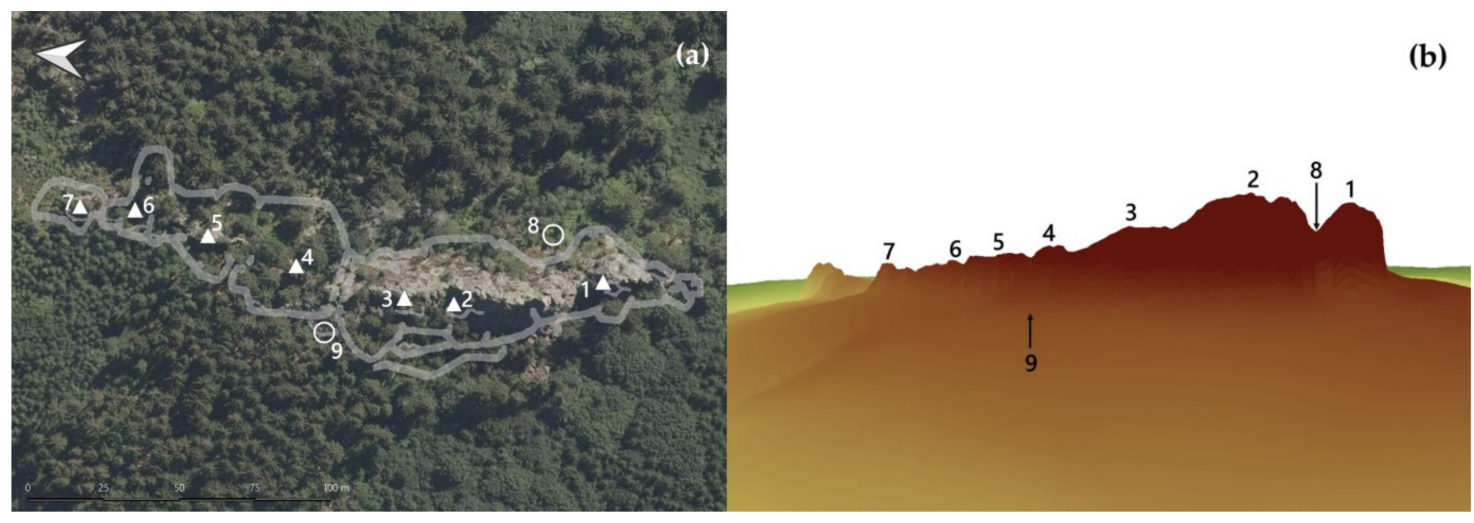

Figure 2. (a) Specific outcrops of Drátenická skála on the orthophoto image [56]). (b) Digital terrain model of Drátenická skála rock formation from the south [57,58]. Names of particular outcrops and other formations: 1-Orlí věž (Eagle's tower), 2-Otoman, 3-Sokol (Falcon), 4-Zbojnická věž (Brigand’s tower), 5-Indiánská věž (American Indian’s tower), 6-Opičí věžka (Monkey’s pinnacle), 7—Kosá věžka (slant pinnacle), 8-Krakonošova zahrádka (Krakonoš garden), and 9—tunnel.

\subsection{Baseline of the Study}

Our study in the area of Drátenická skála was inspired by the approach of Jan Lacina, the Czech landscape ecologist, who conducted several studies of changes in the landscape through monitoring and assessment based on comparing the contemporary real visual situation of the localities with landscape paintings by Czech artists. His study was aimed, for example, at evaluating changes in the ecological conditions in the chosen localities in the Vysočina region [10]. Another study focused on the changes around contemporary water dam localities [59]. These ideas were the initial material for our concept and were complemented by computer modelling using GIS.

Another idea that was included in this study is linked with unique outcrop management plans in protected areas that consist of stand-thinning and rock exposure through the use of new visual axes $[60,61]$. This very slow and deliberate procedure should lead to previous biotope conditions before spruce afforestation, as well as to higher species diversity (e.g., Peregrine Falcon, Falco peregrinus L., nesting is expected), ecological stability, strengthening forest functions, and stabilising microclimatic functions important for rare species occurrence (e.g., [62-64]). This process is anchored in management plans of Malínská skála, Bílá skála, Černá skála, and Devět skal reservations [64-67]. However, these days, not only does the Czech Republic have to face the largest bark beetle infestation in recent history, the PLA Žd'árské vrchy probably will not stay passed, and we must count on other endangering events. Thus, that intended management would be influenced by the outbreak to some extent, as the outcrops are not surrounded by the original stands of European beech (F. sylvatica), silver fir (A. alba), and sycamore maple (Acer pseudoplatanus L.) but, largely, by Norway spruce (P. abies). These stands are truly threatened by spruce bark beetle (Ips typhographus L.) and may go extinct in a few years.

\subsection{Methodological Approach}

With an effort to reach our aims described in Section 1.1 (Figure 3), the approach started by looking for the most appropriate outcrop locality within Žd'árské vrchy; however, this choice depended on the required visual attractiveness, available landscape paintings, photographs, and other materials. After this exploration, Drátenická skála was selected as the most suitable outcrop area because of its high visual attractiveness and potential special management, as characterised above [68]. Due to the stand-thinning process and new visual axes that have not yet been designed, we focused on modelling the spruce bark beetle outbreak at the locality.

Drátenická skála was artistically rendered by several painters from the Vysočina region. The following authors and their work were included in the research (Figure 4):

- Josef Jambor, Zima pod Drátníkovou skálou, 1954; 
- Josef Jambor Horní Blatiny, 1946; and

- Milan Zimmermann, Dráteníky u Samotína, 2005.

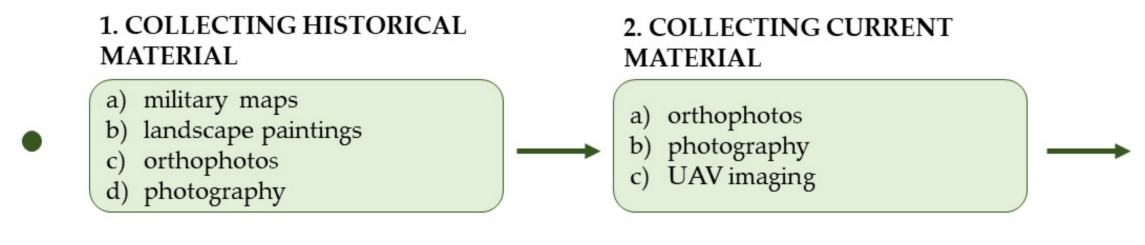

\begin{tabular}{l} 
3. GIS MODELLING OF CURRENT \\
SITUATION \\
$\begin{array}{l}\text { a) DTM and DSM calculation } \\
\text { b) orthophoto and NDVI stand } \\
\text { classification } \\
\text { c) 3D modelling of current } \\
\text { situation } \\
\text { d) visibility analyses }\end{array} \quad \longrightarrow \begin{array}{l}\text { a) modelling the situation after } \\
\text { bark beetle infestation } \\
\text { visibility analyses }\end{array}$ \\
\hline
\end{tabular}

Figure 3. The general scheme of the workflow during the research on Drátenická skála. GIS: geographical information system, DTM: digital terrain model, DSM: digital surface model, NDVI: normalized difference vegetation index, and UAV: unmanned aerial vehicle.

The extent of the forest around the rock formation can also be estimated from the old maps. In the Czech lands, several historical maps are available, such as products from the 1st, 2nd, and 3rd military mappings, which served as the basic material for modern cartography in the 20th century (Figure 5).

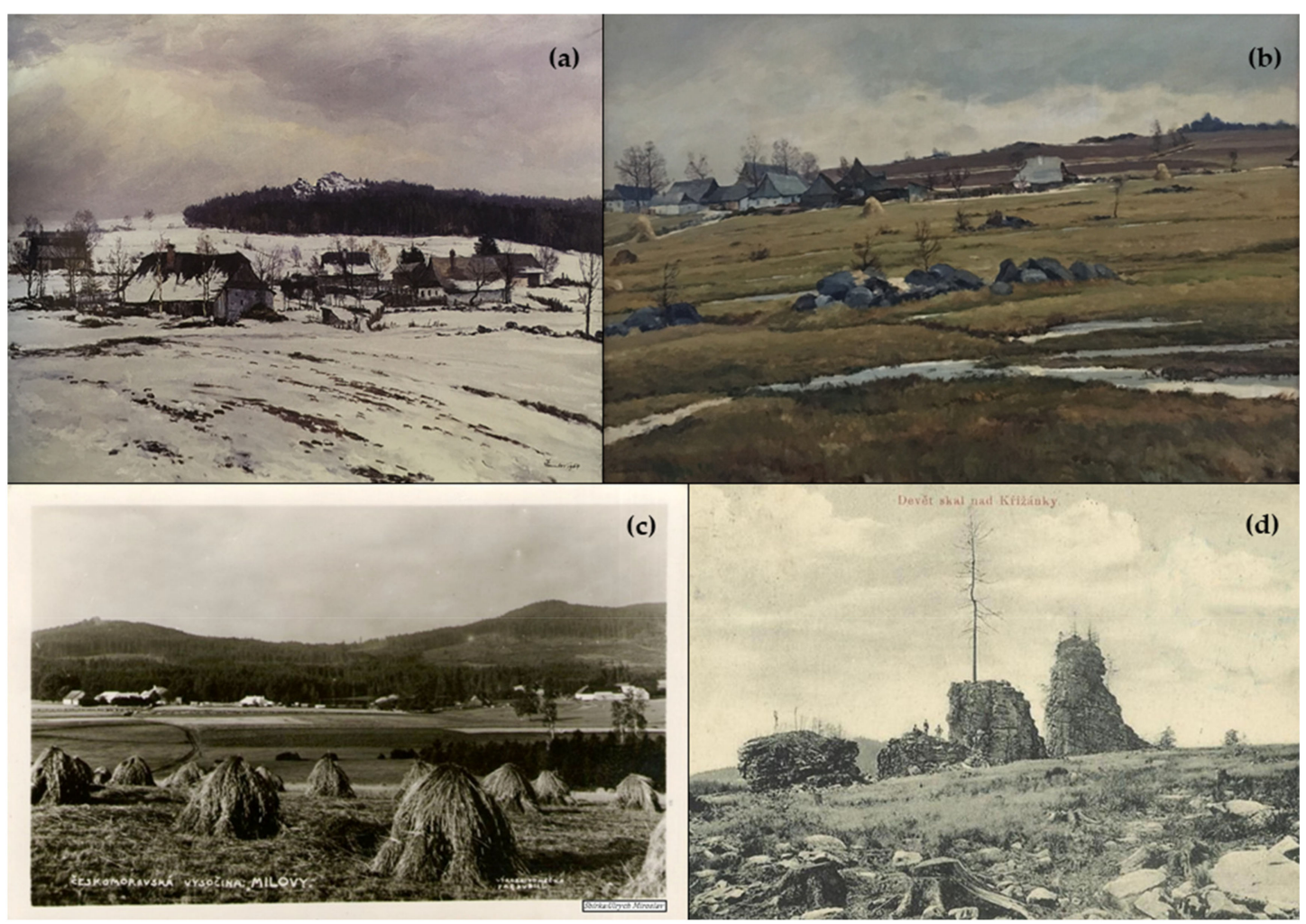

Figure 4. Drátenická skála in the landscape paintings of local artists and in historical photographs (a) Zima pod Drátníkovou skálou (Winter under Drátenická skála), Josef Jambor, 1954; (b) Horní Blatiny, Josef Jambor, 1946; (c) Milovy with Drátenická and Malínská skála in background, 1941 [69]; and (d) uncovered outcrops of Devět skal after windbreak in 1930 [69]. 
We experienced considerable difficulty in locating relevant historical photography; nevertheless, the shot of haymaking in Milovy (1941) with Drátenická skála in the background was discovered (Figure 4). Additionally, historical airborne orthophotos offered quite different but also highly rewarding landscape views. Currently, this rock formation represents one of the most popular objects in the region for photographers and artists (Figure 6).

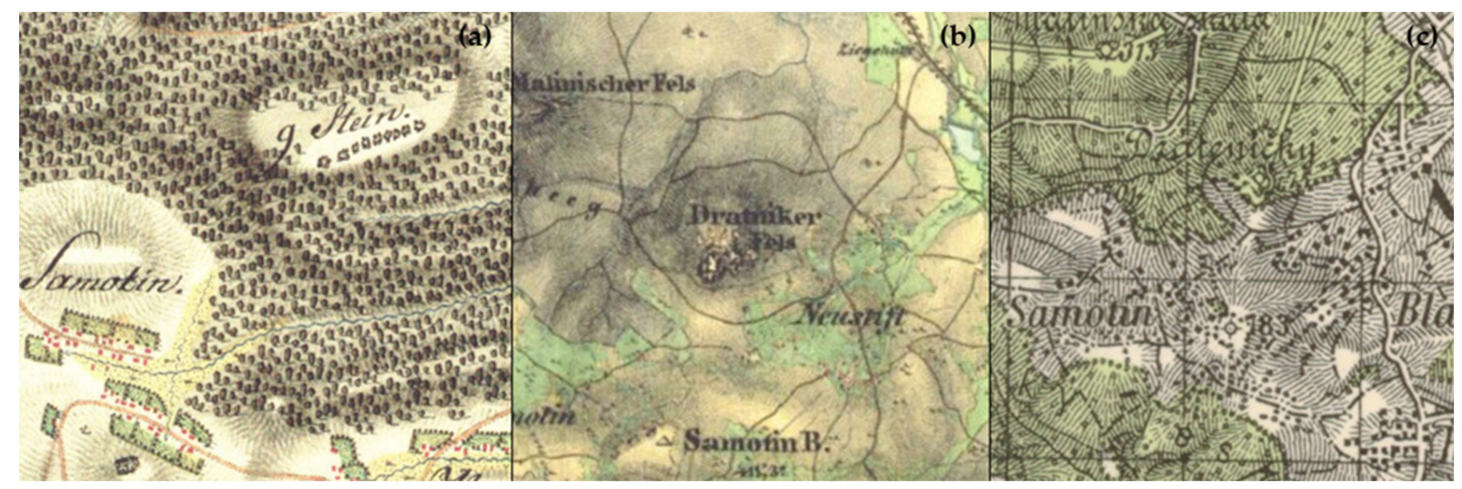

Figure 5. Drátenická skála and its surroundings on the maps (a) of the 1st (1764-1768), (b) of the 2nd (1836-1852), (c) and of the 3rd (1876-1878) military mappings [70-73].

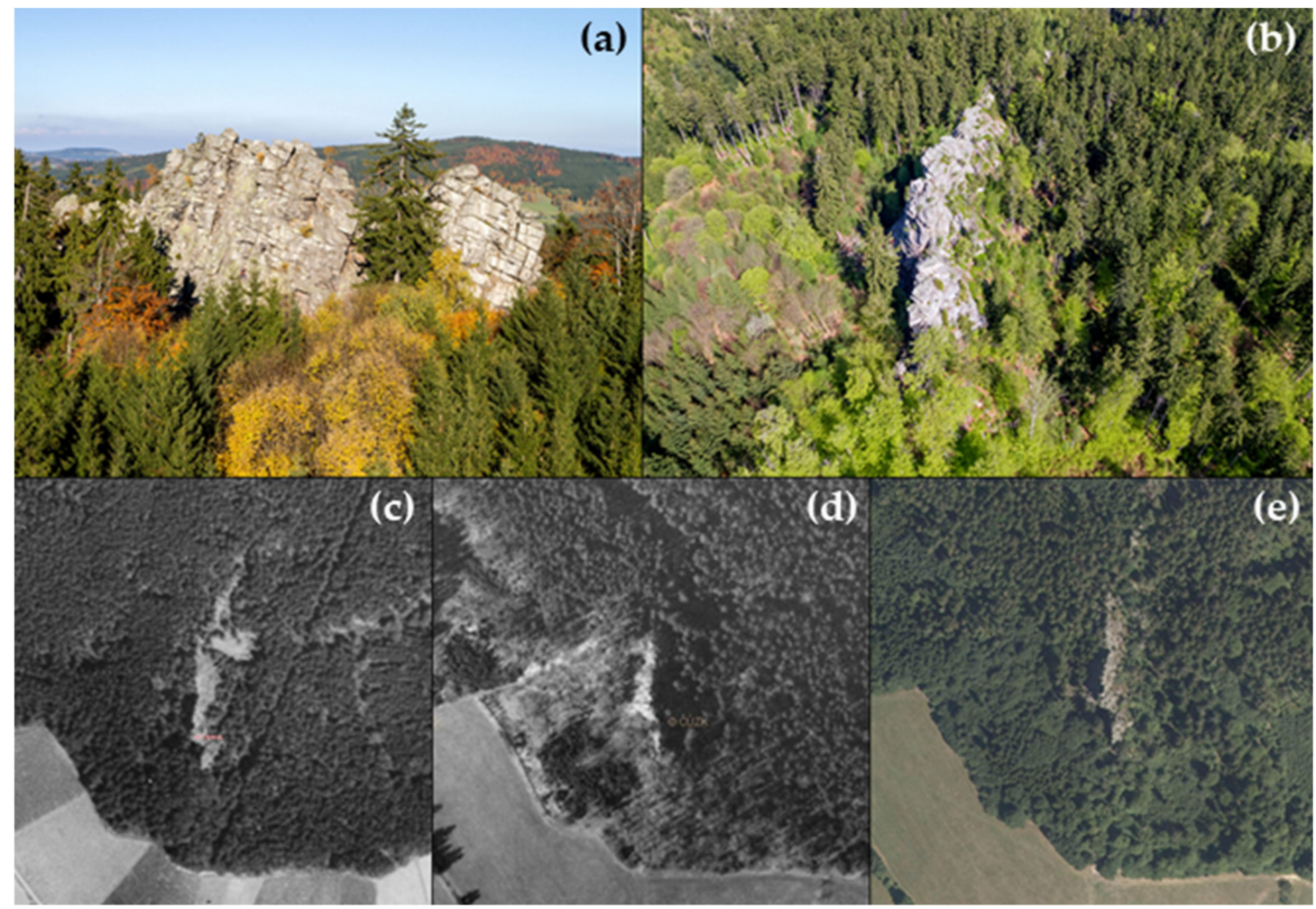

Figure 6. (a,b) Drátenická skála aerial photography taken by an RC (remote control) micro-copter (author: Lubomír Dajč, 2012), (c) historical orthophoto from 1953, (d) historical orthophoto from 1998, and (e) historical orthophoto from 2018 [57].

Our remote-sensing analyses consisted of imaging the locality with a UAV. We used a fixed-wing UAV: the senseFly eBee Plus, which was equipped with a Parrot Sequoia+ multispectral camera (both products manufacturer: senseFly Parrot Group, Rout de Genève 38, 1033 Cheseaux-sur-Laussane, Switzerland) [74]. This camera has a global shutter and four spectral bands with 1.2 Mpix resolution: green $(550 \mathrm{~nm} \pm 40 \mathrm{~nm})$, red $(660 \mathrm{~nm} \pm 40 \mathrm{~nm})$, red edge $(735 \mathrm{~nm} \pm 10 \mathrm{~nm})$, near infrared $(790 \mathrm{~nm} \pm 40 \mathrm{~nm})$, and a separate RGB camera w 16 Mpix resolution and a rolling shutter. The camera is also equipped 
with a sunshine sensor for automatic radiometric calibration. The separate inertial measurement unit and magnetometer were also included. The UAV flight mission was carried out at a mean height of $159.2 \mathrm{~m}$ above the terrain with $60 \%$ lateral and $80 \%$ longitudinal overlap in the resulting ground sample distance (GSD) of $15 \mathrm{~cm} / \mathrm{px}$ for spectral bands. The distance between the photos within one flight line was $29 \mathrm{~m}$, the flight line spacing was $77 \mathrm{~m}$, and the single image coverage was $192 \times 144 \mathrm{~m}$. In total, 520 multispectral images were captured. A postprocessed kinematic (PPK) method was used to improve the image position accuracy. Differential corrections in the one-second sampling rate were created using a virtual reference station (VRS) based on the Czech network of GNSS permanent stations (CZEPOS). These differential corrections were imported into the eMotion software to improve GNSS accuracy. The resulting root mean square error (RMSE) of position coordinate error of the image taken by the UAV was $0.018 \mathrm{~m}$ for $\mathrm{XY}$ and $0.022 \mathrm{~m}$ for Z. The RMSE after block bundle adjustment was $0.005 \mathrm{~m}$.

By processing the captured image data using a well-known workflow in Agisoft Metashape, the point clouds (Figure 7), detailed RGB orthophotos and orthomosaics for each spectral band were obtained. Using the SfM point cloud, the digital surface model (DSM) was calculated by the nearest neighbour interpolation method with a raster resolution of $0.1 \mathrm{~m}$. The digital terrain model (DTM) was calculated by the same method at the same resolution by utilising the LiDAR point cloud data from the Czech State Administration of Land Surveying and Cadastre (ČÚZK). Subtracting these two raster models, the vegetation height was calculated, which is presented as the so-called canopy height model (CHM). With the inverse watershed segmentation method [75], individual tree crowns were identified automatically, as were the top and height of each tree. During this process, the neighbourhood circle radius for $\mathrm{CHM}$ smoothing by focal statistics was experimentally estimated. The best results were achieved using a 1.7-m radius. The pixels located lower than $3 \mathrm{~m}$ above the ground were removed from the model to eliminate low vegetation, which does not influence visual conditions of the locality. These raster data were converted to vector format to prepare them to align with orthophoto data. The CHM, treetop position, and height served to visualise the situation by the 3D model.

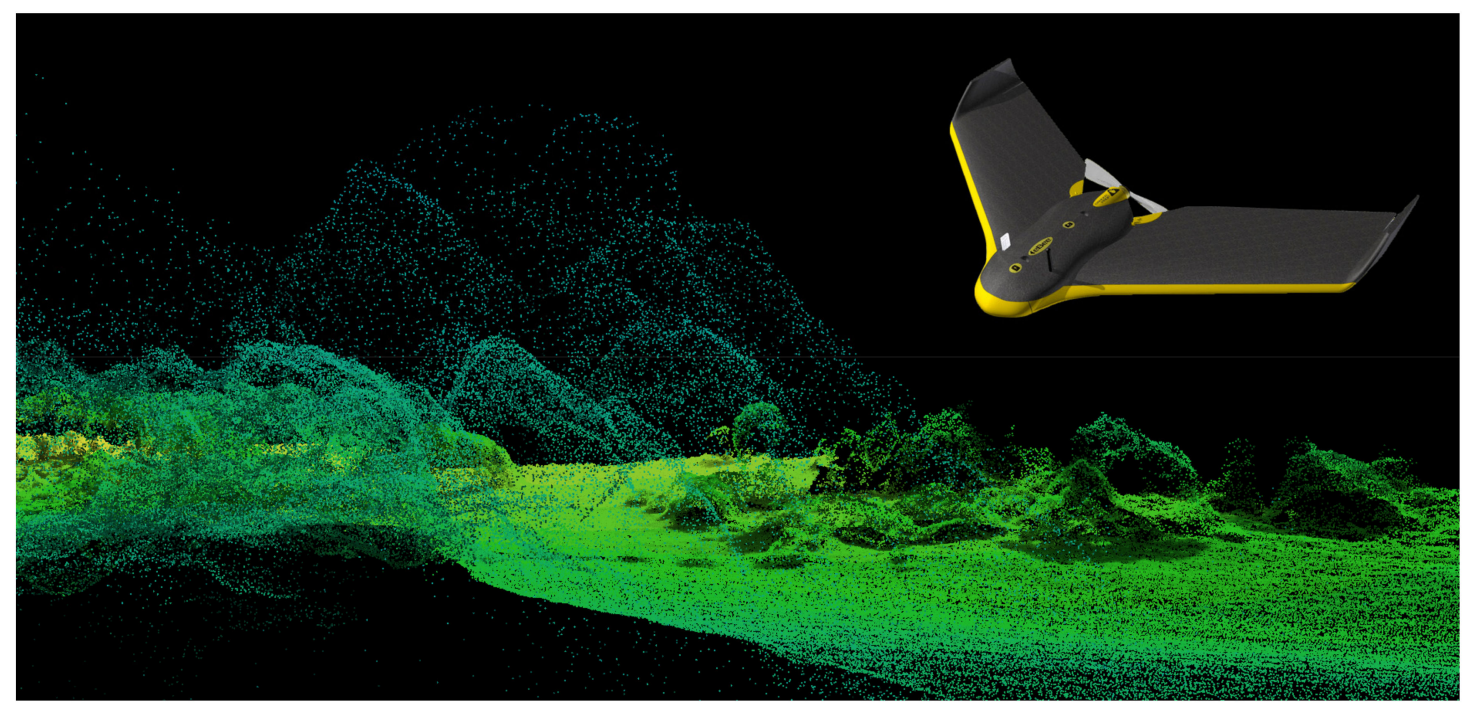

Figure 7. Preview of the loosened point clouds of Drátenická skála with surrounding vegetation cover in FugroViewer software (this is not the full point density) and the UAV (unmanned aerial vehicle) senseFly eBee Plus.

To determine coniferous and deciduous trees, two raster images: true orthophoto and normalized difference vegetation index (NDVI) of the forest stands around the rock were used. However, there are other indices that could be created from the Sequoia+ cameras that are useful for tree species determination, e.g., normalized difference red edge index (NDRE), enhanced vegetation index (EVI) or soil-adjusted vegetation index (SAVI), and canopy chlorophyll content index (CCCI). 
The orthophoto was taken during the UAV flight and is a combination of red, green, and blue bands. For these analyses, iso cluster unsupervised image classification was conducted in ArcMap 10.7, because RGB orthophoto pixels were distributed into 20 colour classes. Then, compared with RGB orthophoto, these 20 classes were classified to represent the coniferous or deciduous trees based on the fact that each tree type has a specific spectral reflectance. Classes representing canopy shadows were erased.

The Zonal Statistics tool served to determine whether the majority pixels within each individual tree crown area were coniferous or deciduous. Through this analysis, the crowns were classified as coniferous or deciduous.

The NDVI is one of the basic vegetation indices that shows how much chlorophyll is contained in a plant. The idea is based on the fact that chlorophyll strongly absorbs visible light (wavelengths 0.4-0.7 $\mu \mathrm{m}$ ) during photosynthesis, whereas a specific plant cell arrangement strongly reflects the near-infrared light spectrum $(0.7-1.1 \mu \mathrm{m})$. By this, it is possible to quantify the photosynthesis capacity of particular pixels expressed by NDVI values ranging between -1 and 1 . Generally, we can say that a significantly higher intensity of reflected near-infrared light than absorbed red light represents dense vegetation (forests, draws, etc.), whereas the opposite case represents thin vegetation (grassland, withered, or damaged trees, etc.). We used the red and near-infrared bands obtained by a spectral UAV camera for NDVI calculation according to the following equation [76]:

$$
\mathrm{NDVI}=\left(\rho_{\mathrm{NIR}}-\rho_{\text {red }}\right) /\left(\rho_{\mathrm{NIR}}+\rho_{\text {red }}\right) \text {. }
$$

Then, the NDVI raster was classified into coniferous and deciduous trees in the same way as the orthophoto.

To complete the visual conditions model around the outcrop, visibility analyses of the rock peak were also performed, as it was calculated for contemporary forest area and for the situation without coniferous stands.

To identify the visible rock borders, we counted that, in the rock area, there was minimal altitudinal difference between the DTM and DSM. Consequently, visible rock was extracted during the removal of low vegetation. To eliminate errors, manual control of the orthophoto was performed as the fastest and most suitable choice for gaining rock borders with the highest possible accuracy.

\section{Results and Discussion}

\subsection{Historic and Artistic Material}

In local galleries, three landscape paintings of Drátenická skála dated from 1946, 1951, and 2005; one photograph dated from 1941 (Figure 4); and a historical orthophoto dated from 1953 and others from the turn of the 20th and 21st centuries (Figure 5) were found. The situation in the 19th century was estimated from the second and third military mapping (1836-1852 and 1876-1878), and the maps of the first military mapping belonged to the 18th century (1764-1768). Last, the named maps were not rigorously positioned, and the rock formation was not specifically depicted either. It was not possible to determine the area of the forest around the outcrop. The two subsequent military mappings better determined the rock position, as well as the area of the surrounding forest. In particular, the second military mapping showed it as a relatively significant visual landscape feature (Figure 5).

The stand area in the first half of the 20th century could be estimated with the help of the collected paintings and photographs. After a detailed survey and identification of a presumable author location, it was obvious that forests were formed by young planting of spruce, so the trees were not as high as they are currently, and the rock was more exposed. Additionally, in other historical photography, this trend was also obvious-for example, the outcrop of Devět skal (Figure 4) was exposed completely, and moth infestation events were documented from the beginning of the 20th century, whether it was nun moth infestations (1920-1922) or windbreaks in November 1930. Much more intensive spruce afforestation followed, and these monocultures contemporarily reached the top parts of many local rock formations, some of which are now completely covered by transformed forest and have artificial 
spatial and species composition. In the example of Drátenická skála, we observed a partial stand loss from the south, where there are shorter broadleaves. This situation is very close to the required result of the PLA management plan. When viewed from the other site, the rock is surrounded mainly by spruce monocultures or mixed stands with spruce dominance. This statement is also supported by both historical and contemporary orthophotos (Figure 6).

\subsection{GIS Modelling}

By applying the GIS procedures described above, the DTM and DSM were created. The area of visible rock and the vegetation lower than $3 \mathrm{~m}$ were erased from the DSM, and the canopy height model (CHM) of the current stand extent was obtained (Figure 8).

By determining the individual tree crowns, assessing their heights, and categorising them as deciduous or coniferous, we obtained a detailed overview of the stand spatial arrangement and structure in the immediate surroundings of the rock formation.

For the tree classification, two types of spectral image-based data were used: suitably-coloured orthophotos and NDVI. However, we must expect some degree of inaccuracy, because some pixel classes represented both tree types at a similar rate, and shades also play an important role in iso cluster unsupervised classification (Figure 8).

For the following analysis of the spatial species composition, the area within a 250-m radius from the centre of the outcrops was evaluated in greater detail. Classification of both the orthophoto and NDVI achieved similar results at the stand level (Tables 1 and 2), but significant differences at the tree level were discovered (Tables 3 and 4). The UAV flight occurred in September, when the differences between the coniferous and deciduous leaves were evident (especially when we mainly distinguished spruce and beech with various green hues; the chlorophyll content in deciduous leaves also decreases during autumn). This was crucial to make the most accurate possible classification. It can be assumed that much worse results would be achieved during image capture in different seasons, especially in the case of orthophoto-based classification. Unfortunately, it was not possible to perform NDVI thresholding for further use. It is always necessary to reclassify the images, because the vegetation has a different chlorophyll content in different seasons. The NDVI value could also be influenced by the water content. Therefore, supervised classifications and machine-learning methods are more successful for more complex analyses, such as health assessments [32].

In terms of the basic wood composition, the stand comprised $42 \%$ deciduous trees and $58 \%$ coniferous trees. The average whole stand height was $22.2 \mathrm{~m}$, with $16.5 \mathrm{~m}$ for deciduous trees and $25.8 \mathrm{~m}$ for coniferous trees. Individual deciduous crown areas were mainly larger than those of coniferous trees, and the lower tree trunk density in deciduous and mixed stands corresponded with this difference. Stand density was highest on the northern side, where spruce predominance was apparent, whereas, on the southern side, where deciduous and mixed stands prevailed, the dispersion and openness of the forest were obviously higher (Figure 8). This situation could roughly correspond to the resulting state after the intended management plan measures.

Comparing this classification with the forest stand map (for our purposes, this map was simplified into three categories according to the main stand type-coniferous, deciduous, or mixed), we can state that our NDVI-based classification corresponded to this map, because the coniferous stands were $85 \%$ coniferous trees, deciduous stands were $81 \%$ deciduous trees, and the proportions of the two tree types in mixed stands were approximately $55 \%$ vs. $45 \%$, respectively. It follows that, by using the unsupervised classification, a quite accurate differentiation of coniferous and deciduous trees was reached (Figure 9 and Table 2). The following step consisted of 3D modelling of the present stand appearance and then modelling the situation that could potentially occur as a result of a current bark beetle infestation if the nonoptimistic scenario was fulfilled and all the spruce trees died. It should be considered that not all coniferous species were spruce, as other species (larch, pine, and fir-approximately $4 \%$, altogether) were present [77], and they were also erased from the model during this step. This scenario could be remodelled for the situation when the bark beetle, for example, did not affect the mixed stands. 
In Figure 10, the visualisation of this change is shown from one of the most attractive points of view in the comparison with the actual photography and landscape in the paintings.

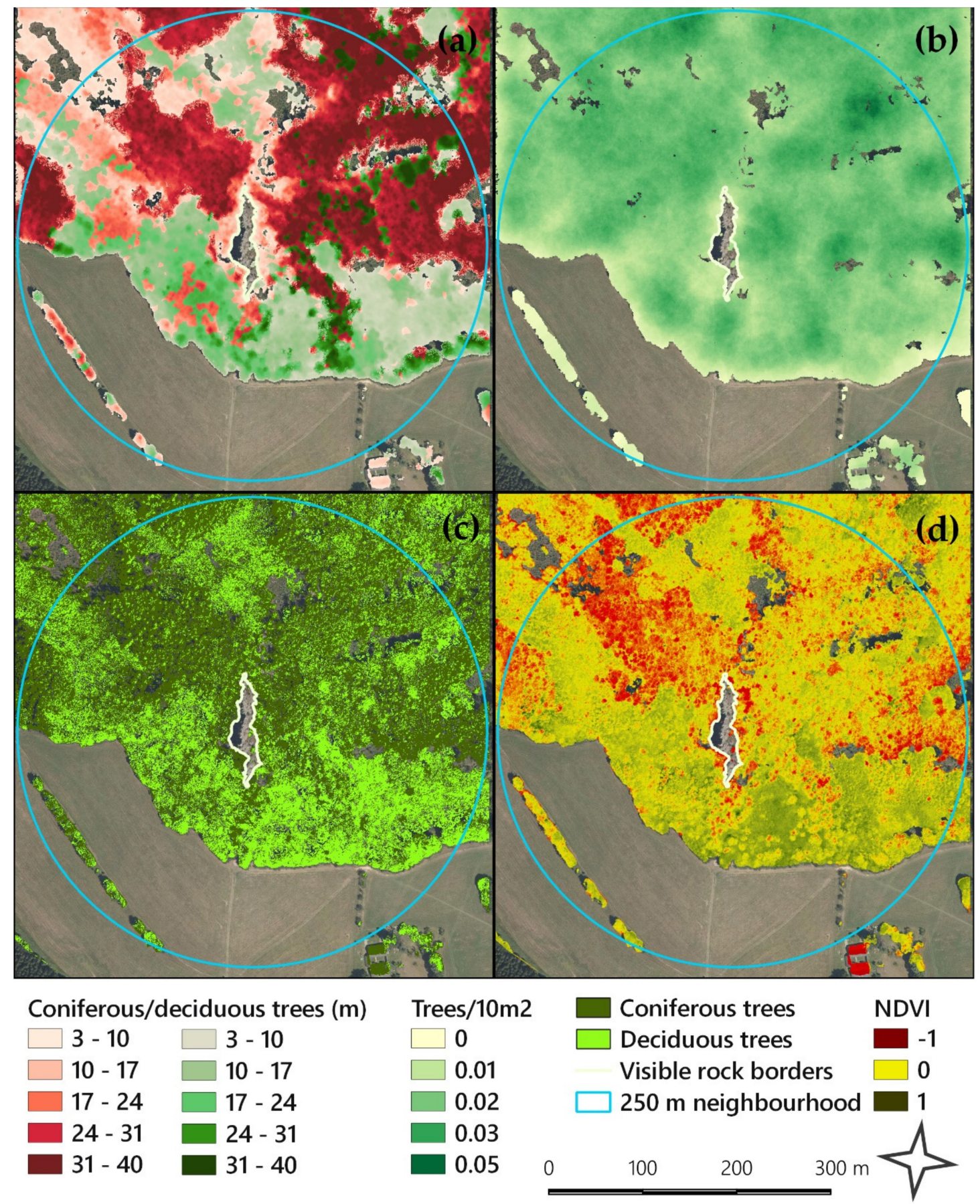

Figure 8. (a) Canopy height model—coniferous (red) and deciduous (green) trees and their heights, (b) stand tree density-number of trees per $10 \mathrm{~m}^{2}$, (c) the result of orthophoto pixel classification into deciduous or coniferous trees, and (d) NDVI (normalized difference vegetation index)—values below zero generally corresponded to coniferous trees, whereas the values above zero indicated deciduous trees. 
Table 1. Orthophoto and NDVI (normalized difference vegetation index) image stand classification into deciduous and coniferous trees.

\begin{tabular}{llccccc}
\hline & & $\begin{array}{c}\text { Number } \\
\text { of Trees }\end{array}$ & $\begin{array}{c}\text { Area } \\
\left(\mathbf{m}^{\mathbf{2}}\right)\end{array}$ & $\begin{array}{c}\text { Density } \\
\left(\text { Trees/1000 } \mathbf{~ m}^{\mathbf{2}}\right)\end{array}$ & $\begin{array}{c}\text { Part of Stands } \\
\text { Area } \mathbf{( \% )}\end{array}$ & $\begin{array}{c}\text { Average } \\
\text { Height }(\mathbf{m})\end{array}$ \\
\hline \multirow{2}{*}{ Orthophoto } & Deciduous stand & 1233 & 59543 & 20.7 & 42.7 & 16.5 \\
& Coniferous stand & 2125 & 79696 & 26.6 & 57.3 & 25.8 \\
\hline \multirow{2}{*}{ NDVI } & Deciduous stand & 1172 & 58975 & 19.8 & 42.4 & 16.8 \\
& Coniferous stand & 2186 & 84871 & 25.8 & 57.6 & 25.4 \\
\hline & Total & 3358 & 139.249 & 25.8 & 100.0 & 22.2 \\
\hline
\end{tabular}

Table 2. Deciduous and coniferous trees were assigned to stands according to the forest stand map [77] (values in bold: total values - number of trees or percentage - for each of the three stand types throughout the whole area).

\begin{tabular}{|c|c|c|c|c|c|}
\hline \multirow{2}{*}{\multicolumn{2}{|c|}{$\begin{array}{c}\text { Stands According } \\
\text { to FSM * }\end{array}$}} & \multicolumn{2}{|c|}{ Number of Trees } & \multicolumn{2}{|c|}{ Part of Whole Area/Stands (\%) } \\
\hline & & Orthophoto & NDVI & Orthophoto & NDVI \\
\hline \multirow[t]{3}{*}{ Conifer } & & 1246 & 1246 & 37.0 & 37.0 \\
\hline & Con. & 1006 & 1065 & 80.1 & 85.4 \\
\hline & Dec. & 240 & 214 & 19.9 & 14.6 \\
\hline \multirow[t]{3}{*}{ Decidu } & & 402 & 402 & 12.4 & 12.4 \\
\hline & Con. & 111 & 83 & 25.2 & 19.1 \\
\hline & Dec. & 291 & 319 & 75.8 & 80.9 \\
\hline \multirow[t]{3}{*}{ Mixed } & & 1710 & 1710 & 50.6 & 50.6 \\
\hline & Con. & 1008 & 1038 & 53.1 & 55 \\
\hline & Dec. & 702 & 672 & 46.9 & 45 \\
\hline Sum & & 3358 & 3358 & 100.0 & 100.0 \\
\hline
\end{tabular}

Confusion matrices (Tables 3 and 4) for classification of the NDVI and orthophotos were computed based on 200 stratified accuracy points. Visual investigation of the orthophotos was used as the ground truth classification.

Table 3. Confusion matrix for NDVI-based classification.

\begin{tabular}{lcccc}
\hline Class & Coniferous Trees & Deciduous Trees & Total & User's Accuracy \\
\hline Coniferous trees & 95 & 7 & 102 & 0.9314 \\
Deciduous trees & 10 & 88 & 98 & 0.8980 \\
Total & 105 & 95 & 200 & \\
Producer's accuracy & 0.9048 & 0.9263 & & 0.9150 \\
\hline Kappa & 0.8298 & & & \\
\hline
\end{tabular}

Table 4. Confusion matrix for the orthophoto-based classification.

\begin{tabular}{lcccc}
\hline Class & Coniferous Trees & Deciduous Trees & Total & User's Accuracy \\
\hline Coniferous trees & 85 & 17 & 102 & 0.8333 \\
Deciduous trees & 20 & 78 & 98 & 0.7959 \\
Total & 105 & 95 & 200 & \\
Producer's accuracy & 0.8095 & 0.8211 & & 0.8150 \\
\hline Kappa & 0.6296 & & & \\
\hline
\end{tabular}




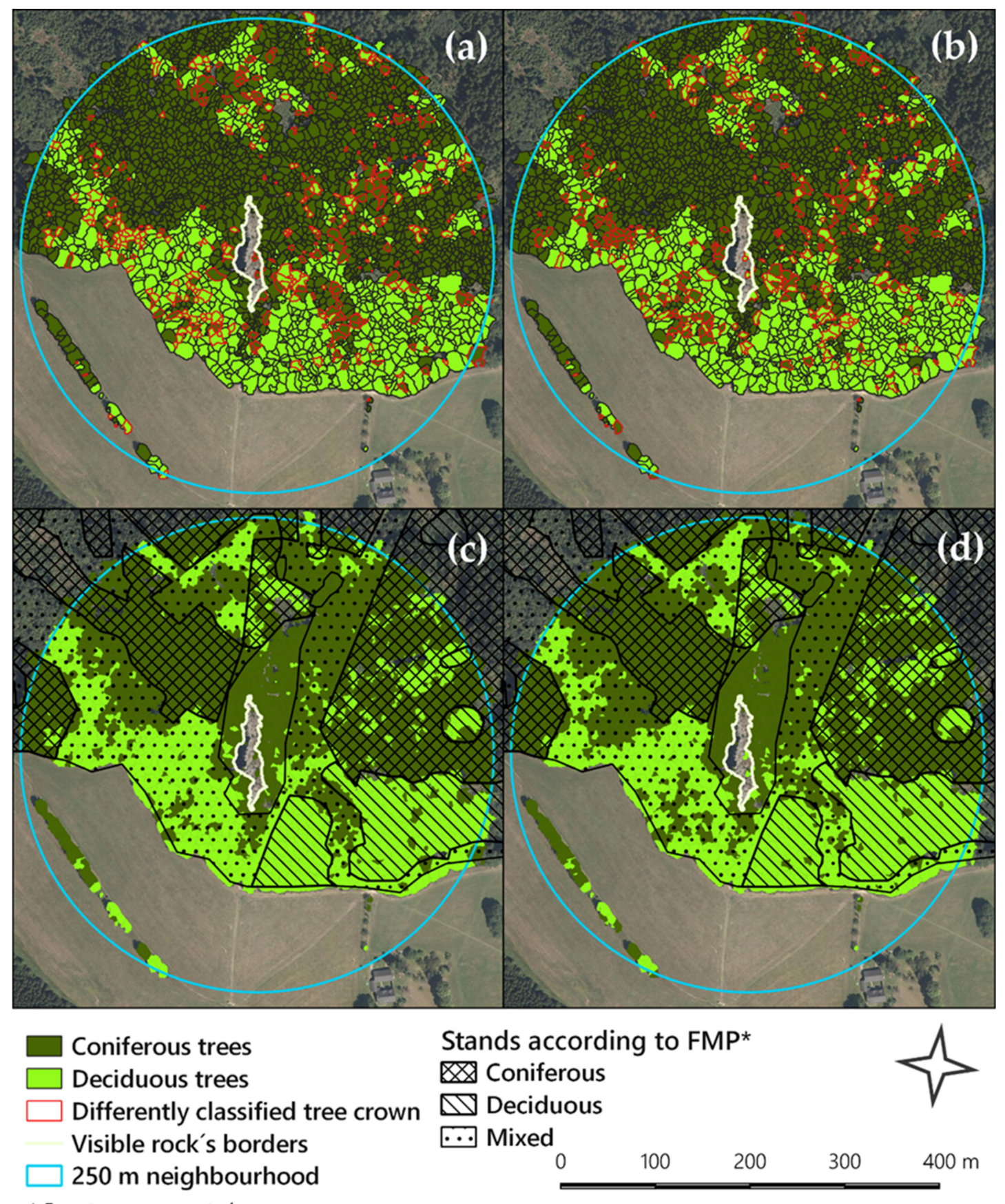

* Forest management plan

Figure 9. (a) The result of orthophoto tree classification, (b) the results of NDVI image classification and the differences between them (red polygons), (c) comparison of the orthophoto classification with a simplified forest stand map, and (d) and comparison of the NDVI classification with a simplified forest stand map.

At the tree level, the NDVI-based classification was significantly more successful. However, both classifications had very balanced types of errors. Nevertheless, the error of omission within the classification of the deciduous trees was the highest (deciduous trees were more often mistakenly classified as coniferous) in both classifications.

With these basic data and models, the choice to design various possible situations was then quite simple to apply. In practice, the process could consist of the localisation of trees considered to be felled by global navigation satellite systems during the field survey. These localised trees were related to 
the canopy height model of the crowns, erased, and, in accordance with the process described above (Section 2.3), the 3D model of this new planned visual tree composition was designed. By this approach, we will be able to choose the most appropriate measures leading to stand-thinning and conversion.

By using more detailed image classification, it would also be possible to determine various tree species and operate with better differentiation, which could enable us to focus on more specific situations, such as mortality in a particular species, as a consequence of other insect pests, from bacterial, viral, and fungal diseases or due to increased drought sensitivity. Practical use of this approach is suitable mainly for the care of similar specially protected areas that are valuable by their visual attractiveness or in the care of less extensive forest properties. For larger forest complexes, UAV imaging is still too uneconomical; however, it is possible to use freely available spectral satellite data with high $(10-30 \mathrm{~m})$ or very high resolutions $(0.3-10 \mathrm{~m})$, which are commonly used in current forest remote sensing.

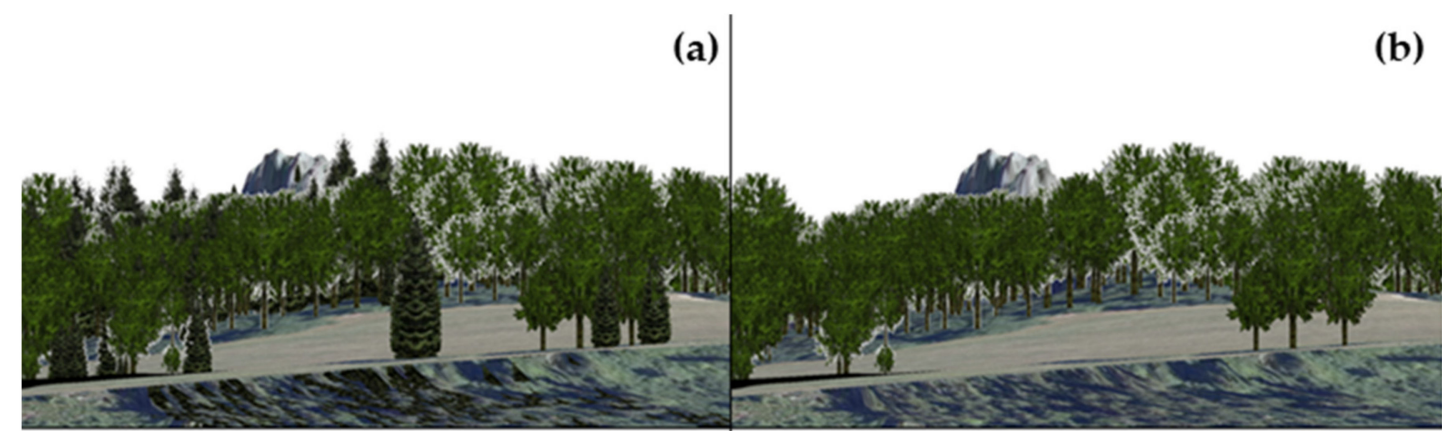

(c)

(d)

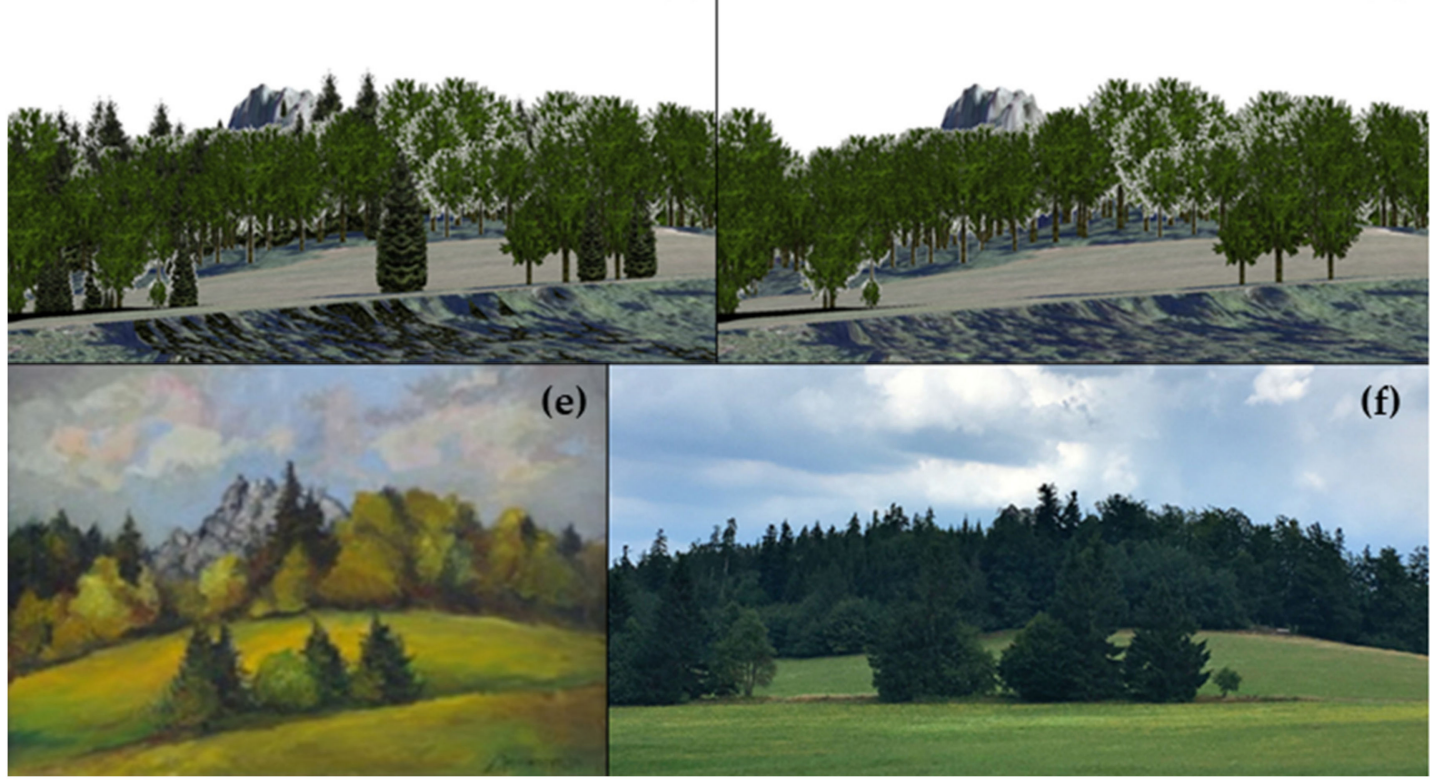

Figure 10. 3D (three-dimensional) models of forests around Drátenická skála based on the orthophoto and NDVI classification results-tree type and position: (a) orthophoto-current situation, (b) orthophoto-potential situation after bark beetle infestation, (c) NDVI-current situation, (d) NDVI-potential situation after bark beetle infestation, (e) similar view in the landscape painting Dráteníky u Samotína, Milan Zimmermann, 2005, and (f) similar view in current photography (author: Marie Balková, 2019).

Additionally, a visibility model was calculated for both situations: with and without coniferous trees. We analysed from which places the rock peak (776 MASL) was visible when it was covered by contemporary forest stands and from which it would be visible with total conifer mortality. These models were compared within the $335,801-\mathrm{m}^{2}$ surrounding area polygon (Figure 11 and Table 5). 
The peak was visible from $3.9 \%$ of the area $\left(13,216.8 \mathrm{~m}^{2}\right)$, and in the case of a model without conifers that was identified by the NDVI-based classification, it was visible from $14.4 \%$ of the area $\left(48,338.5 \mathrm{~m}^{2}\right)$.

Table 5. Areas from which the peak was visible as determined by the visibility model and type of tree identified by NDVI classification.

\begin{tabular}{ccccc}
\hline $\begin{array}{c}\text { Places in Relation } \\
\text { to Peak Visibility }\end{array}$ & \multicolumn{2}{c}{ Situation in $\mathbf{2 0 1 9}$} & \multicolumn{2}{c}{ Situation without Coniferous } \\
\cline { 2 - 5 } & Area $\mathbf{( m}^{\mathbf{2}} \mathbf{\%}$ & $\begin{array}{c}\text { \% of the } \\
\text { Area }\end{array}$ & Area $\left.\mathbf{( m}^{\mathbf{2}}\right)$ & \% of the Area \\
\hline Visible & $13,216.80$ & 3.90 & $48,388.50$ & 14.40 \\
Invisible & $322,584.20$ & 96.10 & $287,412.50$ & 85.60 \\
Whole area & $335,801.00$ & 100.00 & $335,801.00$ & 100.00 \\
\hline
\end{tabular}

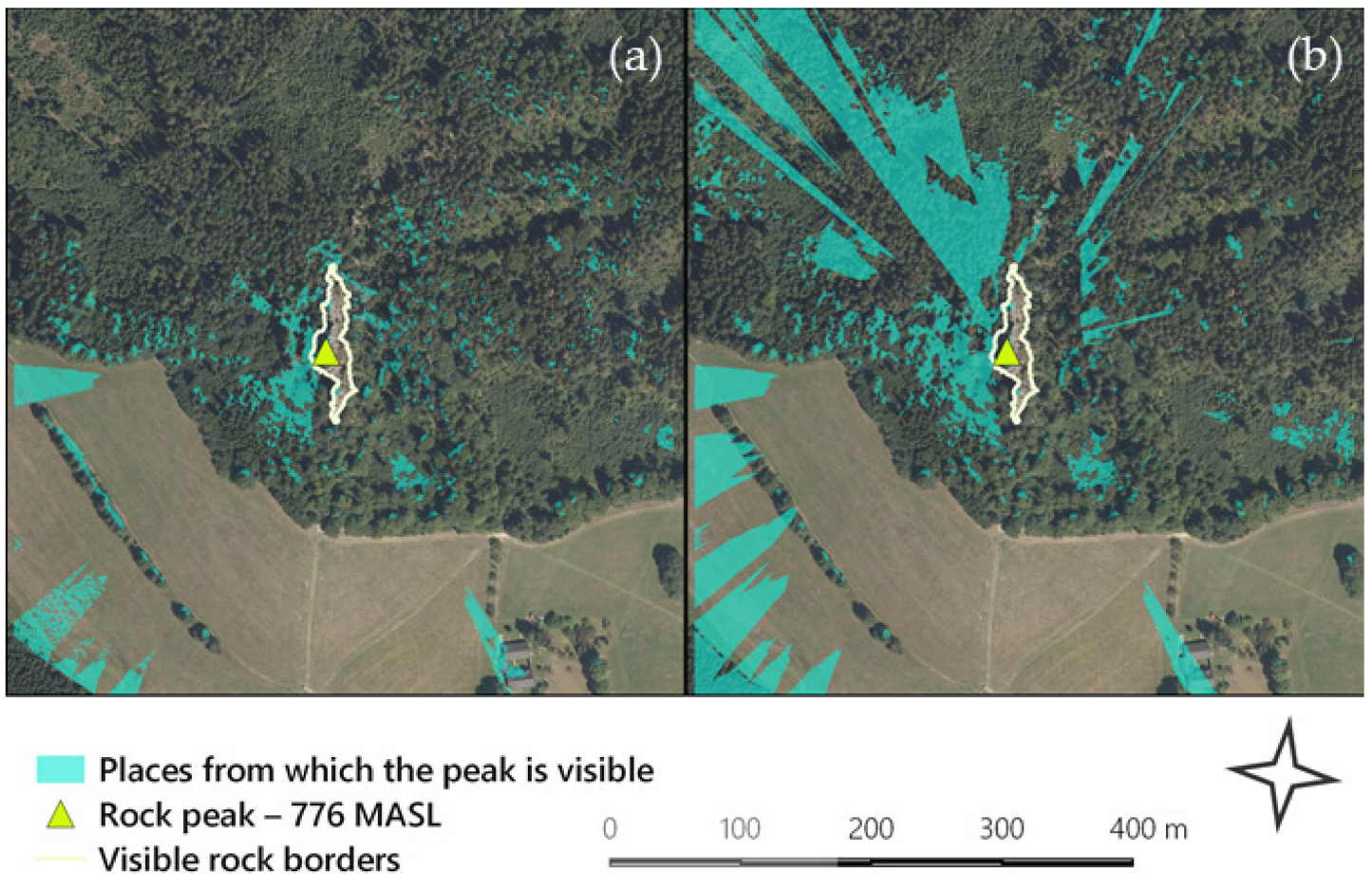

Figure 11. The results of the visibility analyses: (a) contemporary situation of the forest stand and (b) visibility conditions using the model without conifers (gained by NDVI classification).

\section{Conclusions}

In this study, the development of forest cover around Drátenická skála over the last few centuries was depicted and evaluated using historical maps, orthophotos, photography, and landscape paintings by local artists. The GIS analysis consisted of taking data by UAV scanning and then computing each tree location, crown area, and height. The tree type (deciduous or coniferous) determination was realised using orthophoto and NDVI image unsupervised classifications. Higher classification accuracy was demonstrated on the basis of the NDVI, especially at the tree level. These processes led to the creation of forest cover and visual rock formation models that corresponded well to the real situation that was documented by the forest stand map. Additionally, a model of the possible situation after a bark beetle calamity, which would kill all spruce trees, was created. Finally, the visibility analysis was added for both forest stand situations. Another modelling method was discussed in connection with the fact that the spruce monoculture growth is naturally considered to not be the best current method, and the current PLA management relies on the transformation and opening of the stands.

This study can contribute to effective management planning specifically in outcrop localities that are being rebuilt with the aim of protecting microclimatic life conditions for endangered species that 
are dependent on these specific habitats. This study can also be helpful during any outbreaks of tree species diseases that threatens to kill the stands.

Author Contributions: Conceptualisation, Marie Balková, Aleš Bajer, and Tomáš Mikita; data curation, Zdeněk Patočka and Tomáš Mikita; investigation, Marie Balková; methodology, Marie Balková, Aleš Bajer, and Zdeněk Patočka; resources, Marie Balková; software, Marie Balková, Zdeněk Patočka, and Tomáš Mikita; supervision, Aleš Bajer and Tomáš Mikita; validation, Aleš Bajer and Tomáš Mikita; and writing-mid-draft, Marie Balková, Aleš Bajer, Zdeněk Patočka and Tomáš Mikita. All authors have read and agreed to the published version of the manuscript.

Funding: This research and the APC were funded by Internal Grant Agency of Faculty of Forestry and Wood Technology, Mendel University in Brno, Czech Republic, grant number LDF_TP_2019012 "Remote Sensing to Support the Sustainability of Forest Production Under the Condition of Ongoing Climate Change".

Acknowledgments: We would like to thank Petra Gregorová from Horácká galerie in Nové Město na Moravě for her kind support in finding and reproducing the landscape paintings and Marcela Vraspírová from Galerie Vysočiny Polička for the permission to use the painting reproductions. Our thanks also belong to Lubomír Dajč for providing his aerial photographs. Special thanks are owed to the organisers of the GIS Ostrava 2020-UAV in Smart City and Smart Region conference. This article was published in the special issue for this conference, and an abstract was published in the proceedings, which can be found at this link: http://gisak.vsb.cz/GIS_Ostrava/GIS_Ova_2020/proceedings/papers/gis20205e33e0d8b1b75.pdf.

Conflicts of Interest: The authors declare no conflicts of interest.

\section{References}

1. Cartwright, J. Ecological islands: Conserving biodiversity hotspots in a changing climate. Front. Ecol. Environ. 2019, 17, 331-340. [CrossRef]

2. Peñaloza-Bojacá, G.F.; de Oliviera, A.B.; Teixeira Araújo, C.A.; Fantecelle, B.L.; dos Santos, D.N.; Maciel-Silva, A. Bryophytes on Brazilian ironstone outcrops: Diversity, environmental filtering, and conservation implications. Flora 2018, 238, 162-174. [CrossRef]

3. Speziale, K.L.; Ezcurra, C. Rock outcrops as potential biodiversity refugia under climate change in North Patagonia. Plant Ecol. Divers. 2015, 8, 353-361. [CrossRef]

4. Do Carmo, F.F.; Jacobi, C.M. Diversity and plant trait-soil relationships among rock outcrops in the Brazilian Atlantic rainforest. Plant Soil 2016, 403, 7-20. [CrossRef]

5. Balková, M.; Bajer, A. An Unconventional Promotion of Rock Outcrops in Žd'árské Vrchy PLA Using Remote Sensing. In Public Recreation and Landscape Protection-With Nature Hand in Hand! Conference Proceeding, 1st ed.; Mendel University in Brno: Brno-sever-Černá Pole, Czech Republic, 2018; pp. $23-27$. ISBN 978-80-7509-550-3. Available online: http://www.utok.cz/sites/default/files/data/USERS/u24/RaOP\% 202018_WEB_1_0.pdf (accessed on 10 August 2019).

6. Henshillwood, C.S.; d’Errico, F.; van Niekerk, K.L.; Dayet, L.; Queffelec, A.; Pollarolo, L. An abstract drawing from the 73,000-year-old levels at Blombos Cave, South Africa. Nature 2018, 562, 115-118. [CrossRef]

7. Clottes, J. The 'three Cs': Fresh avenues towards European Paleolithic Art. In The Archeoloy of Rock Art; Chippindale, C., Tacon, P.S.C., Eds.; Cambridge University Press: Cambridge, UK, 2018.

8. Chauvet, J.M.; Brunel Deschamps, E.; Hillaire, C. Dawn of Art: The Chauvet Cave: The Oldest Known Paintings in the World; H.N. Abrams: New York, NY, USA, 1996.

9. Robb, J. Prehistoric art in Europe: A deep-time social history. Am. Antiq. 2015, 80, 635-654. [CrossRef]

10. Lacina, J.; Halas, P. Landscape painting in evaluation of changes in landscape. J. Landsc. Ecol. 2015, 8, 60-68. [CrossRef]

11. Wehr, A.; Lohr, U. Airborne laser scanning-An introduction and overview. ISPRS J. Photogramm. Remote Sens. 1999, 54, 68-82. [CrossRef]

12. Baltsavias, E.P. Airborne laser scanning: Existing systems and firms and other resources. ISPRS J. Photogramm. Remote Sens. 1999, 54, 164-198. [CrossRef]

13. Brázdil, K. Technická Zpráva k Digitálnímu Modelu Reliéfu 5. Generace (DMR 5G) (Technical Report of the Digital Terrain Model of the Czech Republic of the 5th Generation (DTM5G)); State Administration of Land Surveying and Cadastre: Prague, Czech Republic, 2012. 
14. Mikita, T. Hodnocení přesnosti digitálního modelu povrchu 1. generace v lesních porostech a možnosti využití dat v lesnické praxis (Evaluation of accuracy of the digital surface model of the 1st generation in forest stands and possibilities of data usage in forestry practice). Geod. Kartogr. Obz. 2014, 12, 317-323.

15. Mikita, T.; Cibulka, M.; Janata, P. Hodnocení přesnosti digitálních modelů reliéfu 4. A 5. generace v lesních porostech (Evaluation of accuracy of the digital terrain models of the 4th and 5th generation in forest stands and possibilities of data usage in forestry practice). Geod. Kartogr. Obz. 2013, 4, 76-85.

16. Iglhaut, J.; Cabo, C.; Puliti, S.; Piermattei, L.; O'Connor, J.; Rosette, J. Structure from motion photogrammetry in forestry: A review. Curr. For. Rep. 2019, 5, 155-168. [CrossRef]

17. Goodbody, T.R.H.; Coops, N.C.; White, J.C. Digital aerial photogrammetry for updating area-based forest inventories: A review of opportunities, challenges, and future directions. Curr. For. Rep. 2019, 5, 55-75. [CrossRef]

18. Michez, A.; Piégay, H.; Lisein, J.; Claessens, H.; Lejeune, P. Classification of riparian forest species and health condition using multi-temporal and hyperspatial imagery from unmanned aerial system. Environ. Monit. Assess. 2016, 188, 146. [CrossRef] [PubMed]

19. Brovkina, O.; Cienciala, E.; Surový, P.; Janata, P. Unmanned aerial vehicles (UAV) for assessment of qualitative classification of Norway spruce in temperate forest stands. Geo Spat. Inf. Sci. 2018, 21, 12-20. [CrossRef]

20. Puliti, S.; Ørka, H.O.; Gobakken, T.; Naesset, E. Inventory of small forest areas using an unmanned aerial system. Remote Sens. 2015, 7, 9632-9654. [CrossRef]

21. Tuominen, S.; Balazs, A.; Saari, H.; Pölönen, I.; Sarkeala, J.; Viitala, R. Unmanned aerial system imagery and photogrammetric canopy height data in area-based estimation of forest variables. Silva Fenn. 2015, 49, 1348. [CrossRef]

22. Mikita, T.; Janata, P.; Surový, P. Forest stand inventory based on combined aerial and terrestrial close-range photogrammetry. Forests 2016, 7, 165. [CrossRef]

23. Næsset, E.; Økland, T. Estimating tree height and tree crown properties using airborne scanning laser in a boreal nature reserve. Remote Sens. Environ. 2002, 79, 105-115. [CrossRef]

24. Hyyppä, J.; Inkinen, M. Detecting and estimating attributes for single trees using laser scanner. Photogramm. J. Finl. 1999, 16, 27-42.

25. Guerra-Hernández, J.; Cosenza, D.N.; Rodriguez, L.C.E.; Silva, M.; Tomé, M.; Díaz-Varela, R.A.; González-Ferreiro, E. Comparison of ALS- and UAV(SfM)- derived high-density point clouds for individual tree detection in Eucalyptus plantations. Int. J. Remote Sens. 2018, 39, 5211-5235. [CrossRef]

26. Mohan, M.; Silva, C.; Klauberg, C.; Jat, P.; Catts, G.; Cardil, A.; Hudak, A.T.; Dia, M. Individual tree detection from unmanned aerial vehicle (UAV) derived canopy height model in an open canopy mixed conifer forest. Forests 2017, 8, 340. [CrossRef]

27. Nevalainen, O.; Honkavaara, E.; Tuominen, S.; Viljanen, N.; Hakala, T.; Yu, X.; Hyyppä, J.; Saari, H.; Pölönen, I.; Imai, N.N.; et al. Individual tree detection and classification with UAVbased photogrammetric point clouds and hyperspectral imaging. Remote Sens. 2017, 9, 185. [CrossRef]

28. Lisein, J.; Pierrot-Deseilligny, M.; Bonnet, S.; Lejeune, P. A photogrammetric workflow for the creation of a forest canopy height model from small unmanned aerial system imagery. Forests 2013, 4, 922-944. [CrossRef]

29. Stone, C.; Mohammed, C. Application of remote sensing technologies for assessing planted forests damaged by insect pests and fungal pathogens: A review. Curr. For. Rep. 2017, 3, 75-92. [CrossRef]

30. Näsi, R.; Honkavaara, E.; Lyytikäinen-Saarenmaa, P.; Blomqvist, M.; Litkey, P.; Hakala, T.; Viljanen, N.; Kantola, T.; Tanhuanpää, T.; Holopainen, M. Using UAV-based photogrammetry and hyperspectral imaging for mapping bark beetle damage at tree-level. Remote Sens. 2015, 7, 15467-15493. [CrossRef]

31. Minařík, R.; Langhammer, J. Use of a multispectral Uav photogrammetry for detection and tracking of forest disturbance dynamics. Int Arch Photogramm. Remote Sens. Spat. Inf. Sci. 2016, XLI-B8, 711-718. [CrossRef]

32. Dash, J.P.; Watt, M.S.; Pearse, G.D.; Heaphy, M.; Dungey, H.S. Assessing very high resolution UAV imagery for monitoring forest health during a simulated disease outbreak. ISPRS J. Photogramm. Remote Sens. 2017, 131, 1-14. [CrossRef]

33. Mikita, T.; Klimánek, M.; Cibulka, M. Hodnocení metod interpolace dat leteckého laserového skenování pro detekci stromů a měřená jejich výšek (Evaluation of Airborne Laser Scanning data interpolation methods for tree detection and height measurement). Zprávy Lesn. Výzkumu 2013, 58, 99-106. 
34. Zhao, B.; Wu, J.; Yang, F.; Pilz, J.; Zhang, D. A novel approach for extraction of Gaoshanhe-Group outcrops using Landsat Operational Land Imager (OLI) data in the heavily loess-covered Baoji District, Western China. Ore Geol. Rev. 2019, 108, 88-100. [CrossRef]

35. Chesley, J.T.; Leier, A.L.; White, S.; Torres, R. Using unmanned aerial vehicles and structure-from-motion photogrammetry to characterize sedimentary outcrops: An example from the Morrison Formation, Utah, USA. Sediment. Geol. 2017, 354,1-8. [CrossRef]

36. Mezghani, M.M.; Fallatah, M.I.; AbuBshait, A.A. From drone-based remote sensing to digital outcrop modeling: Integrated workflow for quantitative outcrop interpretation. J. Remote Sens. GIS 2018, 7, 1000237. [CrossRef]

37. Blistan, P.; Kovanič, L'.; Zelizňaková, V.; Palková, J. Using UAV photogrammetry to document rock outcrops. Acta Monast. Slov. 2016, 2, 154-161.

38. Burton-Johnson, A.; Black, M.; Fretwell, P.; Kaluza-Gilbert, J. An automated methodology for differentiating rock from snow, clouds and sea in Antarctica from Landsat 8 imagery: A new rock outcrop map and area estimation for the entire Antarctic continent. Cryosphere 2016, 10, 1665-1677. [CrossRef]

39. Caravaca, G.; Le Mouélic, S.; Mangold, N.; L’Haridon, J.; Le Deit, L.; Massé, M. 3D digital outcrop model reconstruction of the Kimberley outcrop (Gale crater, Mars) and its integration into Virtual Reality for simulated geological analysis. Planet. Space Sci. 2020, 182, 104808. [CrossRef]

40. Mikita, T.; Balková, M.; Bajer, A.; Cibulka, M.; Patočka, Z. Comparison of different remote sensing methods for 3d modeling of small rock outcrops. Sensors 2020, 20, 1663. [CrossRef]

41. Kirchner, K. Žd'árské Vrchy Highland-Geomorphological Landscape in the Top Part of the Bohemian-Moravian Highland with the Unique Crystalline Rocks Forms. In Landscapes and Landforms of the Czech Republic; Pánek, T., Hradecký, J., Eds.; Springer: Cham, Switzerland, 2016; pp. 221-231. ISBN 978-3-319-27536-9. [CrossRef]

42. Rozbory Chráněné krajinné oblasti Žd'árské vrchy (Analyzes of the Žd'árské vrchy Protected Landscape Area), Nature Conservation Agency of the Czech Republic. Available online: https:/drusop.nature.cz/ost/ archiv/plany_pece/index.php?frame\&ID=23662 (accessed on 5 August 2019).

43. Čech, L. Chráněná území ČR, svazek VII.-Jihlavsko (Protected areas of the Czech Republic, Volume VII.-Jihlavsko); Nature Conservation Agency of the Czech Republic: Prague, Czech Republic, 2002; p. 528.

44. Plán Péče o Chráněnou Krajinnou Oblast Žd'árské Vrchy na Období 2011-2020 (Management Plan of Žd'árské Vrchy Protected Landscape Area for the Period 2011-2020), Nature Conservation Agency of the Czech Republic. Available online: https://drusop.nature.cz/ost/archiv/plany_pece/index.php?frame\&ID=23662 (accessed on 5 August 2019).

45. Demek, J.; Mackovčin, P. Zeměpisný lexikon ČR-Hory a nížiny (Geographical Lexicon of the Czech Republic-Mountains and Lowlands); Agency of the Czech Republic: Prague, Czech Republic, 2006; p. 588.

46. Hanžl, P. Geology of the Žd'árské Vrchy Area: A Review, Travaux Géophysiques; Institute of Geophysics, Czech Academy of Sciences: Prague, Czech Republic, 2011; Volume 40, p. 24.

47. Melichar, R.; Buriánek, D.; Břízová, E.; Buriánková, K.; Čurda, J.; Fürych, V.; Hanžl, P.; Kirchner, K.; Lysenko, V.; Mrnková, J.; et al. Vysvětlivky k Základní Geologické Mapě České Republiky 1:25000 (Explanatory Notes to Basic Geological Map of the Czech Republic 1:25000), Sheet 24-111 Sněžné; Czech Geological Survey: Prague, Czech Republic, 2004; p. 58.

48. Bajer, A.; Kirchner, K.; Kubalíková, L. Geodiversity values as a basis for geosite and geomorphosite assessment: A case study from Žd'árské vrchy Highland. In Central Europe Area in View of Current Geography. Proceedings of 23rd Central European Conference, 1st ed.; Masaryk University in Brno: Brno, Czech Republic, 2016; pp. 56-69. ISBN 978-80-210-8313-4.

49. Gray, M. Geodiversity: Valuing and Conserving Abiotic Nature; John Wiley: Chichester, UK, 2004; p. 434.

50. Kubešová, S.; Novotný, I.; Sutorý, K. Inventarizační Průzkum Cévnatých Rostlin A Mechorostů (Inventory Survey of Vascular Plants And Bryophytes) Bílá Skála, Černá Skála, Devět Skal, Drátenická Skála, Lisovská Skála, Malinská Skála, Milovské Perničky, Pasecká Skála, Rybenské Perničky, Vlčí Kámen; Moravian museum: Brno, Czech Republic, 2006; p. 55.

51. Chytrý, M.; Kučera, T.; Kočí, M. Katalog Biotopu České Republiky (Catalog of Habitats of the Czech Republic); Agency of the Czech Republic: Prague, Czech Republic, 2001; p. 220. 
52. Drvotová, M. Měkkýši (Mollusca) Žd'árských Vrchů. (Molluscs (Mollusca) of the Žd'árské vrchy Mts.), Parnassia; Agency of the Czech Republic, Administration of PLA Žd'árské vrchy: Žd'ár and Sázavou, Czech Republic, 2008; Volume 3, p. 79.

53. Svatoň, J. Pavouci (Araneae) Žd'árských vrchů. Faunisticko-ekologická studie. (Spiders (Araneae) of the Žd'árské vrchy Mts. Faunistic and ecology study), Parnassia; Agency of the Czech Republic, Administration of PLA Žd'árské vrchy: Žd'ár and Sázavou, Czech Republic, 2006; Volume 1, p. 100.

54. Kirchner, K.; Roštínský, P. Geomorfologická inventarizace vybraných skalních útvarů v centrální části CHKO Žd'árské vrchy (Geomorphological inventory of selected rock formations in the central part of the PLA Žd'árské vrchy). In Proceedings of the Faculty of Science, University of Ostrava, Geography, Geology; University of Ostrava: Ostrava, Czech Republic, 2007; Volume 237, pp. 48-64.

55. Bajer, A.; Hlaváč, V.; Kirchner, K.; Kubalíková, L. Za Skalními Útvary CHKO Žd'árské Vrchy (To the Rock Formations of the PLA Žd'árské Vrchy); Mendel University in Brno, Institute of Geonics, Czech Academy of Science: Brno, Czech Republic, 2014; p. 88. ISBN 978-80-7375-959-9.

56. Orthophoto of the Czech Republic. WMS Service. State Administration of Land Surveying and Cadastre: Prague, Czech Republic, 2018. Available online: http://geoportal.cuzk.cz/WMS_ORTOFOTO_PUB/ WMService.aspx (accessed on 15 June 2019).

57. Digital Terrain Model of the Czech Republic of the 5th Generation; State Administration of Land Surveying and Cadastre: Prague, Czech Republic, 2013.

58. Doležal, F.; Trefulka, F. Žd'árské vrchy. Průvodce po Horolezeckých Terénech Vysočiny (Guide to Climbing Terrains of the Vysočina Highlands); Physical Education Unity Vysočina: Žd'ár nad Sázavou, Czech Republic, 2006; p. 106.

59. Lacina, J.; Halas, P. Vodní nádrže a jejich krajina ve výtvarném umění (Water reservoirs and their landscape in fine art). Vodohospod. Tech. Ekon. Inf. 2017, 59, 31-39.

60. Doubek, J. Odlesnění skal na Žd'ársku aneb jak se rodí kompromisy (Deforestation of rocks in Žd'ár region, or how compromises are born). Lesnická Práce 2013, 92, 16-18.

61. Hlaváč, V. Znovu k záměru "odlesnění skal" na Žd'ársku (Again to the intention of "rocks deforestation" in the Žd'ár region). Lesn. Pr. 2014, 93, 34-35.

62. Pike, D.A.; Webb, J.K.; Shine, R. Removing forest canopy cover restores a reptile assemblage. Ecol. Appl. 2011, 21, 274-280. [CrossRef]

63. Michael, D.R.; Lindenmayer, D.B.; Cunningham, R.B. Managing rock outcrops to improve biodiversity conservation in Australian agricultural landscapes. Ecol. Manag. Restor. 2010, 11, 43-50. [CrossRef]

64. Plán Péče o Přírodní Památku Malínská Skála na Období 2016-2025 (Management plan of Malínská skála natural monument for the period 2016-2025). Nature Conservation Agency of the Czech Republic. Available online: https://drusop.nature.cz/ost/archiv/plany_pece/index.php?frame\&ID=26881 (accessed on 6 August 2019).

65. Plán Péče o Př́rodní Památku Bílá Skála na Období 2016-2025 (Management plan of Bílá skála natural monument for the period 2016-2025). Nature Conservation Agency of the Czech Republic. Available online: https://drusop.nature.cz/ost/archiv/plany_pece/index.php?frame\&ID=26880 (accessed on 6 August 2019).

66. Plán Péče o Přírodní Památku Černá Skála na Období 2016-2025 (Management plan of Černá skála natural monument for the period 2016-2025). Nature Conservation Agency of the Czech Republic. Available online: https://drusop.nature.cz/ost/archiv/plany_pece/index.php?frame\&ID=26809 (accessed on 6 August 2019).

67. Plán Péče o Přírodní Památku Devět Skal na Období 2016-2025 (Management plan of Devět skal natural monument for the period 2016-2025). Nature Conservation Agency of the Czech Republic. Available online: https://drusop.nature.cz/ost/archiv/plany_pece/index.php?frame\&ID=26805 (accessed on 6 August 2019).

68. Plán Péče o Př́rodní Památku Drátenická Skála na Období 2016-2025 (Management plan of Drátenická skála natural monument for the period 2016-2025). Nature Conservation Agency of the Czech Republic. Available online: https://drusop.nature.cz/ost/archiv/plany_pece/index.php?frame\&ID=26806 (accessed on 29 June 2019).

69. Fotohistorie (Photohistory). Available online: http://www.fotohistorie.cz/Default.aspx (accessed on 2 June 2019).

70. 1st Military Survey, Section No. 15; Austrian State Archive/Military Archive: Vienna, Austria, 2003.

71. 2nd Military Survey, Section No. W_6_II; Austrian State Archive/Military Archive: Archive/Military Archive, 2006.

72. 3rd Military Survey, Section No. 4156; Nature Conservation Agency of the Czech Republic: Prague, Czech Republic, 2009.

73. Oldmaps. Laboratory of Geoinformatics, Jan Evangelista Purkyně University in Ústí nad Labem. Available online: http://oldmaps.geolab.cz (accessed on 7 June 2019).

74. SenseFly Parrot Group. Available online: https://www.sensefly.com/expand/ (accessed on 16 August 2019). 
75. Edson, C.B. Light Detection And Ranging (Lidar): What We Can and Cannot See in The Forest For The Trees; UMI Dissertation Publishing, Oregon State University: Corvallis, OR, USA, 2011; p. 277.

76. Weir, J.; Herring, D. Measuring Vegetation (NDVI and EVI); NASA Earth Observatory: Washington, DC, USA, 2000; Available online: https://earthobservatory.nasa.gov/features/MeasuringVegetation/measuring vegetation_2.php (accessed on 10 August 2019).

77. Geoportal. Forests of the Czech Republic, State-Owned Company. Available online: https://geoportal.lesycr. $\mathrm{cz} / \mathrm{itc} /$ ? serverconf $=$ default\&wmcid=882 (accessed on 22 August 2019).

(C) 2020 by the authors. Licensee MDPI, Basel, Switzerland. This article is an open access article distributed under the terms and conditions of the Creative Commons Attribution (CC BY) license (http://creativecommons.org/licenses/by/4.0/). 